\title{
Efikasi Diri, Pendidikan Kewirausahaan dan Ekspektasi Pendapatan : Pengaruh terhadap Minat Berwirausaha
}

\author{
Ilham Pragosa Satyantoro \\ e-mail:ilhamprag7@omail.com \\ Endah Andayani \\ e-mail: endahandayani@unikama.ac.id \\ Walipah \\ e-mail:walipah@unikama.ac.id
}

(Program Studi Pendidikan Ekonomi, Fakultas Ekonomika dan Bisnis, Universitas PGRI Kanjuruhan,

Malang)

\begin{abstract}
ABSTRAK: Penelitian ini membahas tentang Pengaruh Efikasi Diri, Pendidikan Kewirausahaan dan Ekspektasi Pendapatan terhadap Minat Berwirausaha. Populasi dalam penelitian ini adalah mahasiswa Pendidikan Ekonomi Universitas Kanjuruhan Malang sejumlah 55 mahasiswa, Teknik pengambilan sample menggunakan sampel jenuh sejumlah 55 mahasiswa. Jenis penelitian ini adalah penelitian kuantitatif. Metode statisik penelitian ini menggunakan Regresi Linier Berganda dengan prasyarat uji asumsi klasik uji normalitas, uji multikoloniaritas, uji heteroskesdastisitas, uji autokorelasi pada pengujian hipotesis menggunakan uji $\mathrm{F}$, uji t, uji R. Berdasarkan uji hipotesis menggunakan analisis Regresi Linier Berganda, pada penelitian ini terdapat pengaruh yang signifikan antara variabel bebas terhadap variabel terikat. variabel X1 (Efikasi Diri) berpengaruh signifikan terhadap variabel $Y$ (Minat berwirausaha) dengan nilai signifikan sebesar 0,004, X2(Pendidikan Kewirausahaan) berpengaruh signifikan terhadap Y(Minat Berwirausaha) dengan nilai signifikan sebesar 0047, X3 (Ekspektasi Pendapatan) berpengaruh terhadap variabel Y(Minat Berwirausaha) dengan nilai signifikan sebesar 0,43.
\end{abstract}

Kata kunci - Efikasi Diri, Pendidikan Kewirausahaan, Ekspektasi Pendapatan, Minat Berwirausaha

\begin{abstract}
This study discusses the effect of self-efficacy, entrepreneurship education and income expectations on entrepreneurial interest. The population in this study were 55 students of Economic Education at Kanjuruhan University Malang. The sampling technique used was a saturated sample of 55 students. This type of research is quantitative research. The statistical method of this research uses Multiple Linear Regression with the prerequisites for the classic assumption test of normality, multicoloniarity test, heteroskesdasticity test, autocorrelation test for hypothesis testing using the $F$ test, $t$ test, $R$ test. significant influence between the independent variables on the dependent variable. variable X1 (Self-Efficacy) has a significant effect on variable $Y$ (Entrepreneurial Interest) with a significant value of 0.004, X2 (Entrepreneurship Education) has a significant effect on $Y$ (Entrepreneurial Interest) with a significant value of 0047, X3 (Income Expectation) has a significant effect on variable $Y$ ( Entrepreneurial Interest) with a significant value of 0.43 .
\end{abstract}

Keywords - Self-Efficacy, Entrepreneurship Education, Income Expectations, Entrepreneurial Interest 


\section{PENDAHULUAN}

Indonesia adalah sebuah negara dengan jumlah penduduk yang banyak. Berdasarkan data Badan Pusat Statistik (BPS), Indonesia memiliki jumlah penduduk sebanyak 269 juta jiwa atau 3,49\% dari total populasi dunia (diakses pada www.bps.go.id ). Indonesia berada diperingkat ke empat negara berpenduduk terbanyak di dunia setelah Tiongkok, India, dan Amerika Serikat dalam (http://databok.katadata.co.id) diakses pada 29 november 2019. Sebenarnya tidak hanya penduduk yang banyak, dapat kita lihat Indonesia juga memiliki kekayaan alam yang berlimpah. Melihat hal ini, Indonesia bisa disebut sebagai negara yang memiliki sumber daya yang melimpah baik dari sumber daya manusia mauapun sumber daya alamnya.

Akan tetapi, kekayaan alam dan banyaknya penduduk ini tidak diimbangi dengan sebuah pemanfaatan yang baik. Hastuti (2020:40) memberikan pernyataan mengenai wiraushawan negara Indonesia yang harus puas menduduki ranking 94 dari 137 negara berdasarkan hasil survei Global Interpreneursip Monitor, yang masih dibawa bangsa-bangsa ASEAN lain seperti Singapura, Malaysia, Thailand, dan Filipina yang telah menduduki peringkat 27, 58, 71 dan 84. Dari pernyaataan tersebut, dapat disikapi bahwa kebanyakan masyarakat Indonesia dalam mencari penghasilan lebih memilih bersaing menjadi pegawai. Kenyataannya, lapangan pekerjaan tidak berbanding lurus dengan jumlah pencari kerjanya. Dari beberapa hal diatas, maka masalah yang timbul adalah tingkat pengangguran yang semakin tinggi.

Data Badan Pusat Statisktik mencatat bahwa pengangguran lulusan universitas per agustus 2019 sebanyak 5,67 persen dari total angkatan kerja sekitar 13 juta orang, angka tersebut masih diatas rata-rata pengangguran nasional yang sebesar 5,28 persen. sumber (https://www.inews.id) diaskes pada tanggal 8 Mei 2020. Melihat data ini, bahwa lapangan pekerjaan yang belum bisa menampung semua mahasiswa yang sudah lulus. Sehingga permasalah utama adalah jumlah pengangguran terbuka lulusan universitas yang cukup tinggi.

Melihat dari kondisi demikian, berwirausaha merupakan salah satu jalan yang dapat diambil sebagai langkah yang tepat. Masyarakat diharapkan lebih berfikir untuk membuat sebuah kegiatan usaha dan tidak lagi memiliki pemikiran bahwa pegawai merupakan jalan yang terbaik. Menurut Hastuti Dkk (2020:51) berwirausaha adalah suatu kegiatan yang memiliki banyak kegunaan, salah satunya adalah membuka lapangan pekerjaan baru. Kemudian, dari membuka sebuah usaha baru ini selain mengurangi pengangguran untuk diri sendiri dan juga dapat menyerap tenaga kerja.

Memulai sebuah usaha dibutuhkan minat berwirausaha, ketika seseorang sudah mimiliki sebuah minat yang besar akan berwirausaha, orang tersebut memiliki kemungkinan untuk melakukan kegiatan berwirausaha. Widyaningsih Aryanti (2018:7) menyatakan minat berwirausaha adalah keinginan atau dorongan dalam diri untuk bergerak, menekankan pada hasrat untuk mencapai hal yang terbaik dan kepuasan secara pribadi yaitu kebutuhan melalui kegiatan wirausaha. Banyak faktor yang mempengaruhi seseorang untuk memiliki minat dalam berwirausaha, Gunawan Astuti (2018:5-6) memberikan pendapat yaitu terdapat tiga faktor yang mempengaruhi timbulnya minat yaitu: Dorongan yang berasal dari dalam, motif sosial, dan faktor emosional atau perasaan senang.

Efikasi diri berhubungan dengan pemikiran seseorang tentang kemampuan dalam dirinya. Menurut Imron (2018:54) efikasi diri adalah persepsi mengenai seberapa bagus diri dapat berfungsi dalam situasi tertentu yang berhubungan dengan keyakinan bahwa ia mampu mengerjakan sesuatu sesuai dengan harapan. Menurut pendpatan dari Sanawiri Iqbal (2018:11) Nilai hakiki dari seorang wirausahawan adalah kepercayaan diri. Oleh karena itu seorang yang ingin melakukan kegiatan berwirausaha sebaiknya memiliki sikap percaya diri (efikasi diri) begitupun dengan seorang mahasiswa.

Adanya keyakinan dalam diri bila dibekali dengan sebuah pengetahuan atau pendidikan berwirausaha kemungkinan akan membuat seseorang memliki minat dalam berwirausaha. Menurut 
Hastuti (2020:45) pendidikan kewirausahaan adalah skema ajaran untuk mengembangkan orang agar berwirausaha dengan proses pengembangan pola pikir seorang wirausahawan. Penting bagi mahasiswa untuk benar-benar meresapi setiap ilmu yang mereka terima dari pendidikan kewirausahaan. Karena menurut Hamdani Rizal (2019:52) menyatakan bahwa salah satu tujuan dari pendidikan kewirausahaan pada mahasiswa adalah menumbuh kembangkan minat wirausaha dikalangan pemuda yang berlatar belakang pendidikan tinggi.

Mahasiswa akan memperoleh sebuah pola pikir ketika memulai berwirausaha apakah akan memperoleh untung atau tidak kegiatan usahanya. Menurut Paulus (2014) ekspektasi pendapatan merupakan sebuah angan-angan dalam pemikiran untuk memperoleh pendapatan lebih tinggi. Diperlukan untuk memiliki ekspektasi pendapatan yang baik dari kegiatan berwirausha, karena menurut Kurniati Dwi (2015:71) keinginan untuk memperoleh pendapatan dapat menimbulkan minat untuk berwirausaha. Hasil penelitian dari Setiawan Deden (2016) menemukan ada pengaruh dari Ekspektasi Pendapatan, Lingkungan Keluarga, dan Pendidikan Kewirausahaan yang berpengaruh positif terhadap Minat Berwirausaha. Pembeda dengan penelitan sebelumnya yakni dengan adanya penambahan satu variabel yaitu Efikasi Diri. Efikasi Diri adalah sebuah keyakinan dalam diri seseorang untuk menyelesaikan kegiatan.

Terdapat juga penelitian lain yang dijadikan sebagai sebuah landasan dari penelitian ini, yakni penelitan yang dilakukan oleh Achamad Syaifudin (2017) yaitu hasilnya terdapat pengaruh yang signifikan antara Kepribadian, Lingkungan Keluarga, dan Pendidikan Kewirausahaan terhadap minat berwirausaha dari Mahasiswa Akuntansi Universitas Negeri Yogyakarta. Akan tetapi, berbeda dengan hasil penelitian yang dilakukan oleh Syaifudin (2017) secara parsial kepribadian dan lingkungan keluarga memiliki pengaruh terhadap minat berwirausaha, sedangkan pendidikan kewirausahaan tidak berpengaruh terhadap minat berwirausaha.

Penelitian lain yang yang dilakukan oleh Dian Septianti (2016) hasil menjukkan bahwa terdapat pengaruh signifikan antara motivasi, lingkungan keluarga, dan ekspektasi pendapatan terhadap minat berwirausaha (studi kasus pada mahasiswa Tridinanti Palembang). Sedangakan tedapat perbedaan dengan penelitian dari Sintya (2019) yang menujukan hasil bahwa variabel Ekspektasi Pendapatan tidak berpengaruh terhadap minat berwirausaha Jurusan Akuntansi Universitas Mahasaraswati Denpasar. Dari penelitian ini terdapat perbedaan hasil yaitu ekspektasi pendapatan yang menunjukan hasil yang negatif dan positif. Perbedaan hasil dari kedua penelitan inilah yang membuat peneliti ingin mengukur kembali variabel Ekspektasi Pendapatan, apakah variabel tersebut berpengaruh atau tidak terhadap minat berwirausaha

Melihat dari permasalahan latar belakang di atas, maka peneliti tertarik untuk melakukan penelitian dengan Judul "Pengaruh Efikasi Diri, Pendidikan Kewriausahaan Dan Ekspektasi Pendapatan Terhadap Minat Berwirausaha".

\section{METODE}

Populasi Penelitian ini adalah sebanyak 55 mahasiswa progam studi pendidikan ekonomi Universitas Kanjuruhan Malangangkatan 2016 dan 2017. Teknik mengambil sampel dalam penelitian ini yaitu secara keseluruhan, penarikan sampelnya yaitu menggunakan sampel jenuh atau teknik sensus. Variabel bebas yang digunakan yaitu efikasi diri, pendidikan kewirausahaan dan ekspektasi pendapatan, kemudian variable terikat yang digunakan yaitu minat minat berwirausha.

Metode pengumpulan data dengan angket atau kuisioner. Validitas dan reliabilitas data diperoleh melalui uji coba dari 30 responden yang disebar pada mahasiswa di luar sampel. Angket menggunakan skala likert yang dimodifikasi menjadi 5 alternatif jawaban. Penelitian ini menggunakan metode analisis regresi linier berganda dan dilakukan pengujian hipotesis dengan sebelumnya dilakukan uji prasyarat regresi linier berganda yaitu uji asumsi klasik. pengujian analisis data hasil dari penyebaran angket, peneliti menganalisis dengan menggunakan program SPSS 22.00 for windows. 


\section{HASIL PEMBAHASAN}

Perolehan hasil penelitian yang dilakukan dari pengumpulan data dengan memakai instrumen penelitian skala likert. Pemaparan tersebut meliputi variabel: efikasi diri, pendidikan kewirausahaan, ekspektasi pendapatan, dan minat berwirausaha mahasiswa Progam Studi Pendidikan Ekonomi Universitas Kanjuruan Malang. Berdasarkan hasil uji asumsi klasik diatas bahwa data yang telah memenuhi uji asumsi klasik yang meliputi: uji normalitas, uji multikolinearitas, uji heteroskedastisitas dan uji autokorelasi. Dengan demikian, data memenuhi persyaratan untuk diolah dalam regresi linear berganda. Berdasarkan hasil perhitungan dapat diketahui nilai a: $11,465, b_{1}=0,394, b_{2}=0,237, b_{3}=0,629$, maka dapat disusun persamaan regresi linear berganda sebagai berikut:

$Y=a+b_{1} X_{1}+b_{2} X_{2}+b_{3} X_{3}+e$

$\mathrm{Y}=11,465+0,394\left(\mathrm{X}_{1}\right)+0,237\left(\mathrm{X}_{2}\right)+0,629\left(\mathrm{X}_{3}\right)+\mathrm{e}$

Minat berwirausaha $=11,456+0,394$ (efikasi diri) $+0,237$ (pendidikan kewirausahaan) $+0,629$ (ekspektasi pendapatan).

Persamaan tersebut dapat diartikan:

a. Konstanta sebesar 11,463 memiliki arti jika variabel jika variabel $\mathrm{X}_{1}, \mathrm{X}_{2}$ dan $\mathrm{X}_{3}$ bernilai nol, maka variabel dependen $(\mathrm{Y})$ akan sebesar 11,463.

b. Nilai koefisien regresi variabel $X_{1}$ (efikasi diri) sebesar 0,394, menunjukan besarnya pengaaruh X1 terhadap $\mathrm{Y}$, dikarenakan pengaruhnya positif maka nilainya searah, artinya jika variabel $\mathrm{X}_{1}$ ditingkatkan 1 akan menyebabkan kenaikan Minat berwirausaha sebesar 0,394.

c. Nilai koefisien regresi $X 2$ (pendidikan kewirausahaan) sebesar 0,237, menunjukan besarnya pengaaruh $\mathrm{X} 2$ terhadap $\mathrm{Y}$, dikarenakan pengaruhnya positif maka nialainya searah, artinya jika variabel $\mathrm{X}_{2}$ ditingkatkan 1 akan menyebabkan kenaikan minat berwirausaha sebesar, artinya jika variabel $X_{2}$ ditingkatkan 1 akan menyebabkan kenaikan minat berwirausaha sebesar 0,237.

d. Nilai koefisien regresi X3 (ekspektasi pendapatan) sebesar 0,629, menunjukan besarnya pengaaruh $\mathrm{X} 3$ terhadap $\mathrm{Y}$, dikarenakan pengaruhnya positif maka nilainya searah, artinya jika variabel $X_{3}$ ditingkatkan 1 akan menyebabkan kenaikan minat berwirausaha sebesar 0,629.

\section{Hasil Tes Anova uji F}

Tabel 4 Hasil Tes Anova uji F

\begin{tabular}{llrrrrr}
\multicolumn{8}{c}{ ANOVA $^{\mathrm{a}}$} \\
\hline \multirow{2}{*}{ Model } & $\begin{array}{c}\text { Sum of } \\
\text { Squares }\end{array}$ & Df & $\begin{array}{c}\text { Mean } \\
\text { Square }\end{array}$ & F & Sig. \\
\hline \multirow{3}{*}{1} & Regression & 584,635 & 3 & 194,878 & 13,591 & $0,000^{\mathrm{b}}$ \\
\cline { 2 - 7 } & Residual & 731,291 & 51 & 14,339 & & \\
\cline { 2 - 7 } & Total & 1315,927 & 54 & & & \\
\hline
\end{tabular}

Hasil tes Anova diperoleh nilai Fhitung sebesar 13,591 dengan tingkat signifikan 0,000 karena tingkat signifikan lebih kecil dari 0,05 dan $F_{\text {hitung }}(13,591)>F_{\text {tabel }}(2,78)$ maka variabel $\mathrm{X}_{1}$ (efikasi diri), $\mathrm{X}_{2}$ (pendidikan kewiraushaan), dan $\mathrm{X}_{3}$ (ekspektasi pendapatan) secara simultan berpengaruh terhadap variabel $Y$ (minat berwirausaha) sebesar 13,59\%. sehingga $\mathrm{H}_{3}$ diterima dan $\mathrm{H}_{0}$ ditolak. 


\section{Hasil Uji t}

Tabel 5 Hasil Uji t (Uji Signifikan Parsial)

\begin{tabular}{llccc}
\multicolumn{5}{c}{ Coefficients $^{\mathrm{a}}$} \\
\hline \multicolumn{1}{c}{ Model } & $\mathrm{T}$ & Sig. & Keterangan \\
\hline 1 & (Constant) & 1,390 &, 171 & \\
\cline { 2 - 5 } & Efikasi Diri & 2,985 &, 004 & Signifikan \\
\hline Pendidikan Kewirausahaan & 2,034 &, 047 & Signifikan \\
& & & \\
\hline Ekspetasi Pendapatan & 2,078 &, 043 & Signifikan \\
\hline
\end{tabular}

$\left(\mathrm{H}_{2}\right) \quad$ :Hipotesis penelitian untuk menguji hipotesis kedua $\left(\mathrm{H}_{2}\right)$ adalah sebagai berdasarkan tabel di atas nilai t-hitung untuk variabel $\mathrm{X}_{1}$ (efikasi diri) sebesar 2,985 dengan tingkat signifikan sebesar 0,004 karena tingkat signifikan lebih kecil 0,05 dan thitung $(2,985)>$ trabel $(2,007)$ maka variabel $\mathrm{X}_{1}$ (efikasi diri) berpengaruh signifikan terhadap variabel $\mathrm{Y}$ minat berwirausaha sebesar $29,85 \%$. sehingga $\mathrm{H}_{2}$ diterima dan $\mathrm{H}_{02}$ ditolak.

$\left(\mathrm{H}_{3}\right)$ :Hipotesis penelitian untuk menguji hipotesis ketiga $\left(\mathrm{H}_{3}\right)$ adalah sebagai berikut: pengambilan keputusan untuk menguji hipotesis yang diajukan adalah berdasarkan tabel $4.7 \mathrm{di}$ atas nilai t-hitung untuk variabel $\mathrm{X}_{2}$ (pendidikan kewirausahaan) sebesar 2,034 dengan tingkat signifikan sebesar 0,047. Karena tingkat signifikan lebih kecil 0,05 dan thitung $(2,034)>$ tabel $(2,007)$ maka variabel $\mathrm{X}_{2}$ (pendidikan kewirausahaan) berpengaruh signifikan terhadap variabel $\mathrm{Y}$ minat berwirausaha sebesar 20,34\%. sehingga $\mathrm{H}_{3}$ diterima dan $\mathrm{H}_{03}$ ditolak.

$\left(\mathrm{H}_{4}\right) \quad$ :Hipotesis penelitian untuk menguji hipotesis keempat $\left(\mathrm{H}_{4}\right)$ adalah sebagai berikut: pengambilan keputusan untuk menguji hipotesis yang diajukan adalah berdasarkan tabel 4.7 di atas nilai t-hitung untuk variabel $\mathrm{X}_{3}$ (ekspektasi pendaptan) sebesar 2,078 dengan tingkat signifikan sebesar 0,043. Karena tingkat signifikan lebih kecil 0,05 dan thitung $(2,078)>$ tabel $(2,007)$ maka variabel $X_{3}$ (ekspektasi pendaptan) berpengaruh signifikan terhadap variabel Y minat berwirausaha sebesar 20,78\% sehingga $\mathrm{H}_{4}$ diterima dan $\mathrm{H}_{04}$ ditolak.Tabel 5.

Hasil Uji R2 (Koefisien Determinasi).

Tabel 4.12 hasil uji $\mathbf{R}^{2}$

\begin{tabular}{|c|c|c|c|c|c|c|c|c|c|}
\hline \multirow[t]{2}{*}{ Model } & \multirow[t]{2}{*}{$\mathrm{R}$} & \multirow{2}{*}{$\begin{array}{c}\mathrm{R} \\
\text { Square }\end{array}$} & \multirow{2}{*}{$\begin{array}{l}\text { Adjusted R } \\
\text { Square }\end{array}$} & \multirow{2}{*}{$\begin{array}{l}\text { Std. Error of } \\
\text { the Estimate }\end{array}$} & \multicolumn{5}{|c|}{ Change Statistics } \\
\hline & & & & & $\begin{array}{l}\text { R Square } \\
\text { Change }\end{array}$ & F Change & df1 & $\mathrm{df2}$ & $\begin{array}{c}\text { Sig. F } \\
\text { Change }\end{array}$ \\
\hline 1 & $.667^{a}$ & 444 & 412 & 3,787 & 444 & 13,591 & 3 & 51 & ,000 \\
\hline
\end{tabular}

Nilai koefisien determinan ( $\mathrm{R}$ Square) menunjukkan besarnya kontribusi seluruh variabel independen yaitu $X_{1}$ (efikasi diri) $X_{2}$ (pendidikan kewiraushaan) dan $X_{3}$ (ekspektasi pendapatan) dengan variabel minat berwirausaha $(\mathrm{Y})$, jadi $\mathrm{R}$ Square 0,444 memiliki makna $\mathrm{X}_{1}$ (efikasi diri) $\mathrm{X}_{2}$ (pendidikan kewiraushaan) dan $\mathrm{X}_{3}$ (ekspektasi pendapatan) mampu memberikan kontribusi sebesar $44,4 \%$ terhadap perubahan minat berwirausaha (Y), dengan demikian sisanya sebesar 66,6\% dipengaruhi oleh variabel lain yang tidak dilakukan oleh peneliti. 


\section{Pengaruh Efikasi Diri, Pendidikan Kewirausahaan, dan Ekspektasi Pendapatan Terhadap Minat Berwirausaha.}

Berdasarkan pada hasil penelitian yang telah dilakukan, diketahui bahwa variabel efikasi diri, pendidikan kewirausahaan, dan ekspektasi pendapatan pengaruh signifikan secara simultan terhadap variabel minat berwirausaha, Oleh karena itu penelitian ini dapat membuat sebuah hipotesis bahwa variabel bebas secara simultan mempengaruhi variabel terikat dengan nilai Fhitung sebesar 13,591 $>$ Ftabel sebesar 2,78, nilai dengan signifikan 0,000 < 0,05 maka H01 ditolak dan Hal diterima. Nilai koefisien determinan pada penelitian ini menunjukkan bahwa efikasi diri, pendidikan kewirausahaan, dan ekspektasi pendapatan secara bersama-sama mempengaruhi minat berwirausaha mahasiswa program studi pendidikan ekonomi Universitas Kanjuruhan Malang angkatan 2016 dan 2017 dengan nilai R Square 0,444 yang dapat diartikan efikasi diri, pendidikan kewirausahaan, dan ekspektasi pendapatan mampu memberikan kontribusi sebsesar $44,4 \%$ terhadap minat berwirauhasa.

Sejalan dengan penelitian yang dilakukan oleh Purwanto (2016)(Purwanto, 2016) dengan judulnya yaitu Pengaruh Efikasi Diri, Pengetahuan Kewirausahaan, Dan Motivasi Berwirausaha Terhadap Minat Mahasiswa Berwirausaha dengan studi kasus yang dilakukan pada Mahasiswa Diploma Pelayaran Universitas Hang Tuah Surabaya. Kesimpulan dari hasil penelitian yang dilakukan oleh Purwanto yaitu efikasi diri, pengetahuan kewirausahaan dan motivasi kewirausahaan berpengaruh terhadap minat berwirausaha. Terdapat pula dua penelitian lain yang dilakukan oleh Setiawan \& Sukanti (2016). Mengenai pengaruh dari Ekspektasi Pendapatan Lingkungan Keluarga Dan Pendidikan Kewirausahaan Terhadap Minat Berwirausaha. Hasil dari penelitian ini menemukan bahawa bahwa variabel Ekspektasi pendapatan, lingkungan keluarga, dan pendidikan kewirausahaan berpengaruh positif terhadap minat berwirausaha dan peneliatian yang dilakukan oleh Bahrurohman (2018). Berjudul Pengaruh Pendidikan Kewirausahaan, Efikasi Diri Dan Kesiapan Instrumentasi Wirausaha Terhadap Minat Berwirausaha mahasiswa yang menunjukkan hasil Pendidikan kewirausahaan, efikasi diri dan kesiapan instrumentasi wirausaha secara signifikan berpengaruh positif dan simultan terhadap minat berwirausaha mahasiswa Fakultas Ekonomi dan Bisnis PTN dan PTS di Sukoharjo. Sedangkan sisanya yaitu sebesar 66,6\% dipengaruhi oleh variabel lain yang tidak diteliti dalam penlitian ini seperti lingkungan keluarga, motivasi berwirausha dan lain sebagainya.

\section{Pengaruh Efikasi Diri Terhadap Minat Berwirausaha}

Berdasarkan pada hasil penelitian yang telah dilakukan, diketahui bahwa variabel efikasi diri berpengaruh secara parsial terhadap minat berwirausaha pada mahasiswa program studi pendidikan ekonomi Universitas Kanjuruhan Malang. Hal tersebut terbukti melalui perhitungan analisis regresi diketahui bahwa terdapat terdapat pengaruh efikasi diri terhadap minat berwirausaha yang diketahui melalui nilai thitung $(2,985)>$ tabel $(2,007)$ dan nilai signifikansi sebesar sebesar $0,004<0,05$ maka sehingga $\mathrm{H}_{02}$ ditolak dan $\mathrm{H}_{\mathrm{a} 2}$ diterima.

Hasil dari penelitian ini sejalan dengan penelitian yang dilakukan oleh Purwanto (2016) mengenai Pengaruh Efikasi Diri terhadap Minat Mahasiswa Berwirausaha. Studi yang dilakukan Pada Mahasiswa Diploma Pelayaran Universitas Hang Tuah Surabaya. dan ada pula penelitian lain yang dilakukan oleh Fardi \& Rani (2019) tentang Pengaruh Efikasi Diri terhadap Minat Berwirausaha mahasiswa Diploma 3 Teknik Sipil Bangunan Gedung FT UNP, hasil dari kedua penelitian ini yaitu secara parsial variabel efikasi diri berpengaruh signifikan terhadap minat berwirausaha pada mahasiswa. Selain dua penelitian tersebut terdapat pula penelitian yang sejalan dengan penelitian ini,yaitu penelitian yang dilakukan oleh Bahrurohman (2018). Mengenai Pengaruh dari Pendidikan Kewirausahaan, Efikasi Diri Dan Kesiapan Instrumentasi Wirausaha Terhadap Minat Berwirausaha mahasiswa. Penelitian ini menunjukkan bahwa efikasi diri juga berpengaruh positif dan signifikan terhadap minat berwirausaha mahasiswa. 
Efikasi diri akan membantu seseorang untuk dapat memilih sebuah keputusan. Keputusan untuk memilih sebuah karir merupakan salah satu hal yang berhubungan dengan efikasi diri. Karena untuk memilih sebuah pekerjaan seseorang akan mempertimbangkan kemampuan apa yang dimilikinya. Pendapat yang dikemukakan oleh Hasmiati dkk (2018:79) mengenai efikasi diri yang rendah dapat membuat seseorang yang meragukan kemampuan dirinya dan sebaliknya dengan seseorang yang memiliki tingkat efikasi tinggi akan memiliki perasaan tenang dalam mendekati tugas dan kegiatan yang sulit. Efikasi diri dapat memberikan stimulus kepada diri sendiri mengenai seberapa besar atau kecil motivasi. Jika efikasi diri mengenai berwirasuaha tinggi, maka minat berwirausahanya akan muncul.

\section{Pengaruh Pendidikan Kewirausahaan Terhadap Minat Berwirausaha}

Berdasarkan pada hasil penelitian yang telah dilakukan, diketahui bahwa variabel pendidikan kewirausahaan berpengaruh secara parsial terhadap minat berwirausaha pada mahasiswa Program Studi Pendidikan Ekonomi Universitas Kanjuruhan Malang. Hal tersebut terbukti melalui perhitungan analisis regresi diketahui bahwa terdapat terdapat pengaruh efikasi diri terhadap minat berwirausaha yang diketahui melalui nilai thitung $(2,034)>$ tabel $(2,007)$ dan nilai signifikansi sebesar sebesar 0,047 $<0,05$ maka $\mathrm{H}_{03}$ ditolak dan $\mathrm{H}_{\text {aз diterima. }}$

Tetapi terdapat temuan yang berbeda, yaitu dengan penelitian yang dilakukan oleh Maulida dkk (2019) tentang pengaruh Pendidikan Kewirausahaan terhadap minat Berwirausaha Mahasiswa STIE Widyagama Lumajang yang menunjukan hasil bahwa pendidikan kewiraushaan tidak berpengaruh terhadap minat berwirausaha. akan tetapi, hasil penelitian ini sejalan dengan temuan penelitian yang dilakukan oleh Syaifudin (2017) menagenai pengaruh Pendidikan Kewirausahaan Terhadap Minat Berwirausaha Mahasiswa Akuntansi dan penelitian penelitian lain yang dilakukan oleh zulatsari \& Soesatyo (2018) tentang Pendidikan kewiraushaan Terhadap Minat Berwirausahapada mahasiswa Jurusan Pendidikan Ekonomi Fakultas Ekonomi Universitas Negeri Surabaya Angkatan 2015, kedua penelitian ini menujukkan hasil bahwavariabel dari pendidikan kewirausahaan berpengaruh yang sejalan, yaitu secara positif dan signifikan terhadap minat untuk berwirausaha.

Pendidikan kewirausahaan adalah suatu disiplin ilmu yang bertitik fokus untuk menambah pengetahuan individu dalam bidang kewirausahaan baik melalu tingkat institusi pendidikan ataupun tingkatan yang lain. Pendapat yang dikemukakan oleh Alma 2018:6) mengenai tujuan dari pendidikan kewirausahaan yaitu untuk membentuk manusia sebagai manusia yang memiliki karakter, pemahaman, dan keterampilan sebagai wirausaha. Lebih jauh lagi, menurut Hamdani Rizal (2019:52) menyatakan bahwa salah satu tujuan dari pendidikan kewirausahaan pada mahasiswa adalah menumbuh kembangkan minat wirausaha dikalangan mahasiswa. Hal ini lah yang akan membentuk seseorang untuk memiliki jiwa kewirausahaan dan kemudian minatnya untuk berwirausaha akan terbentuk.

\section{Pengaruh Ekspektasi Pendapatan Terhadap Minat Berwirausaha}

Berdasarkan pada hasil penelitian yang telah dilakukan, diketahui bahwa variabel ekspektasi pendapatan berpengaruh secara parsial terhadap minat berwirausaha pada mahasiswa program studi pendidikan ekonomi Universitas Kanjuruhan Malang. Hal tersebut terbukti melalui perhitungan analisis regresi diketahui bahwa terdapat terdapat pengaruh ekspektasi pendapatan terhadap minat berwirausaha yang diketahui melalui nilai thitung $(2,078)>$ tabel $(2,007)$ dan nilai signifikansi sebesar sebesar 0,043 $<0,05$ maka sehingga $\mathrm{H}_{04}$ ditolak dan $\mathrm{H}_{\mathrm{a} 4}$ diterima.

Tetapi terdapat temuan yang berbeda, yaitu penelitian yang dilakukan oleh Sintya (2019) tentang pengaruh Ekspektasi Pendapatan terhadapat minat berwirausaha mahasiswa Jurusan Akuntasi di Univeresitas Mahasawati Denpasar, yang menujukkan hasil bahwa Ekspektasi tidak memiliki pengaruh terhadap minat berwirausaha mahasiswa. Akan tetapi, hasil ini seurupa dengan penelitian yang dilakukan oleh Septianti (2016) tentang Pengaruh Ekspektasi Pendaptan Terhadap Minat Berwirausaha (Studi Kasus Pada Mahasiswa Universitas Tridinanti Palembang) dan terdapat 
pula penelitian yang dilakukan oleh Kamma \& Hardiana (2018) tentang pengaruh Ekspektasi Pendapatan terhadap Minat Berwirausaha, dari kedua penelitian ini sama-sama menujukkan hasil bahwa ekspektasi pendapatan secara parsial berpengaruh terhadap minat berwirausaha mahasiswa. Akan tetapi terdapat pula temuan yang berbeda dangan penelitian yang dilakukan oleh

Ekpektasi pendapatan menyangkut suatu pemikiran atau harapan mengenai kinerja seseorang dengan seberapa besar hasil yang bisa diperoleh (pendapatan) dapat berupa uang ataupun manfaat ekonomi lain dari usaha yang telah dilakukan, apakah banyak atau sedikit. Terdapat pula pendapat yang dikemukakan oleh Kurniati Dwi (2015:71) menurutnya keinginan memperoleh pendapatan dari kegiatan berwirausaha akan menimbulkan minat untuk berwirausaha. Menurut Zimmer, Scarborough dan Wilson dalam Setiawan Deden (2016:19) memberikan pendapat mengenai menjadi seorang wirausaha akan memperoleh keuntungan menakjubkan. Berwirausaha akan membuat seseorang memiliki penghasilan dari laba yang diperoleh. Laba yang diperoleh dari kegiatan berwirausaha akan memberikan semangat seseorang untuk melakukan kegiatan usaha Seseorang memiliki ekspektasi pendapatan yang tinggi akan membuat orang tersebut terdorong untuk melakukan kegiatan usaha.

\section{KESIMPULAN}

Dari hasil penelitian yang dilakukan dapat disimpulkan hasil penelitian adalah sebagai berikut: Ada pengaruh yang signifikan secara simultan (bersama-sama) antara variabel independen efikasi diri, pendidikan kewiraushaan, dan ekpektasi pendapatan terhadap minat berwirausaha mahasiswa Program Studi Pendidikan Ekonomi Universitas Kanjuruhan Malang. Terdapat pengaruh yang signifikan secara parsial antara variabel efikasi diri terhadap minat berwirausaha. Terdapat pengaruh yang signifikan secara persial antara variabel pendidikan kewirausahaan terhadap minat berwirausaha. Terdapat pengaruh yang signifikan secara parsial antara variabel ekspektasi pendapatan terhadap minat berwirausaha.

\section{DAFTAR PUSTAKA}

Alma, B. (2018). Kewiraushaan. Bandung: Alfabeta.

Bahrurohman, Y. (2018). Pengaruh Pendidikan Kewirausahaan, Efikasi Diri Dan Kesiapan Instrumentasi Wirausaha Terhadap Minat Berwirausaha Mahasiswa. Prodi Manajemen, Fakultas Ekonomi Dan Bisnis, Universitas Muhammadiyah Surakarta, 1-224.

Fardi, Z., \& Rani, I. G. (2019). Pengaruh Efikasi Diri Terhadap Minat Berwirausaha Mahasiswa Diploma 3 Teknik Sipil Bangunan Gedung FT UNP. Journal of Civil Engineering and Vocational Education, 6(4), 1-5.

Gunawan, F., \& PAstuti, H. B. P. (2018). Senarai Penelitian Pendidikan, Hukum, dan Ekonomi di Sulawesi Tenggara. Yogyakarta: Deepublish.

Hasmiati, Suwardi, Asra, A., \& Viani, A. (2018). Effective Learning Models In Physical Education Teaching. Yogyakarta: Deepublish.

Kamma, H., \& Hardiana, H. (2018). PENGARUH FAKTOR LINGKUNGAN KELUARGA DAN MASYARAKAT, EKSPEKTASI PENDAPATAN, DAN PENDIDIKAN TERHADAP MINAT MAHASISWA DALAM BERWIRAUSAHA. Dinamis: Journal of Islamic Management and Bussiness, 1(1).

Kurniati, D. A. (2015). Kewiraushaan Industri. Yogyakarta: Deepublish.

LINDA RACHMONA ZULATSARI, M., \& SOESATYO, Y. (2018). Pengaruh Literasi Ekonomi Dan Pendidikan Kewirausahaan Terhadap Minat Berwirausaha Pada Mahasiswa Jurusan Pendidikan Ekonomi Fakultas Ekonomi Universitas Negeri Surabaya Angkatan 2015. Jurnal Pendidikan Ekonomi (JUPE), 6(3), 157-160.

P Hastuti, P., Nurofik, A., Purnomo, A., \& Hasibuan, A. (2020). . Kewirausahaan dan UMKM. Yayasan 
Kita Menulis (Onlen).

Purwanto, F. X. A. (2016). Pengaruh Efikasi Diri, Pengetahuan Kewirausahaan, dan Motivasi

Berwirausaha terhadap Minat Mahasiswa Berwirausaha. Aplikasi Pelayaran Dan Kepelabuhan, 6(2), 104-127.

Sanawiri, B., \& Iqbal, M. (2018). Kewirausahaan. jakarta: Ub press.

Septianti, D. (2016). Pengaruh Motivasi, Lingkungan Keluarga dan Ekspektasi Pendapatan Terhadap Minat Berwirausaha(Studi Kasus Pada Mahasiswa Universitas Tridinanti Palembang). Jurnal Ilmiah Ekonomi Global Masa Kini, 7(03), 1-7.

Setiawan, D., \& Sukanti, S. (2016). Pengaruh Ekspektasi Pendapatan, Lingkungan Keluarga dan

Pendidikan Kewirausahaan Terhadap Minat Berwirausaha. Jurnal Profita: Kajian Ilmu Akuntansi, $4(7)$.

Sintya, N. M. (2019). Pengaruh Motivasi, Efikasi Diri, Ekspektasi Pendapatan, Lingkungan Keluarga,

Dan Pendidikan Kewirausahaan Terhadap Minat Berwirausaha Mahasiswa Jurusan Akuntansi

Di Universitas Mahasaraswati Denpasar. Jurnal Sains, Akuntansi Dan Manajemen, 1(1), 337-380.

Syaifudin, A. (2017). Pengaruh Kepribadian, Lingkungan Keluarga Dan Pendidikan Kewirausahaan

Terhadap Minat Berwirausaha Mahasiswa Akuntansi. Profita Edisi 8 Tahun 2017, 2(3), 1-17.

Widyaningsih, A. (2018). Aspek hukum kewirausahaan. Malang: Plinema press. 